\title{
Peran Istri Nelayan dalam Meningkatkan Perekonomian Keluarga di Pulau
}

\section{Tidung}

\author{
"Laili Muzdalifah" ${ }^{1)}$, Wati Nilamsari ${ }^{2)}$ \\ Program Studi Pengembangan Masyarakat Islam, Fakultas Dakwah dan Komunikasi
}

Correspondence author: lelimuzdalifah@gmail.com

Received : 15 Juni 2021

Accepted : 29 September 2021

Published: 30 September 2021

DOI: https://doi.org/10.37012/jpkmht.v3i2.670

\begin{abstract}
ABSTRAK
Pulau Tidung merupakan kawasan yang terletak di Kepulauan Seribu Selatan, wilayah yang terletak di dekat pesisir pantai. Kondisi yang di miliki Pulau Tidung membuat mayoritas penduduknya bergantung pada sektor perikanan. Karena letak yang berdekatan dengan pantai menjadikan pekerjaan yang dominan tertinggi yakni, nelayan dalam hal ini peran di antara suami dan istri turut andil. Sejumlah istri nelayan tidak hanya sibuk dalam mengurus kegiatan rumah seperti membersihkan pakaian keluarga memasak, menyediakan makanan, membersihkan rumah, mencuci pakaian, dan mendidik anak. Akan tetapi lebih dari itu, sudah menjadi konsekuensi istri nelayan yang terkadang pendapatan hasil nelayan tidak menentu setiap waktu karena itu keterlibatan istri nelayan dalam membantu menopang perekonomian keluarga dan mencari nafkah untuk memenuhi kebutuhan seharihari menciptakan peran ganda. Tujuan penelitian ini untuk mengetahui peran istri nelayan dalam meningkatkan perekonomian rumah tangga. Penelitian ini menggunakan pendekatan kualitatif dengan jenis penelitian deskriptif atau studi kasus. Sedangkan untuk pengambilan informan diambil secara purposive sampling yakni, teknik wawancara secara mendalam dan observasi langsung. Bahwa peran istri nelayan antara lain sebagai penjual ikan dan sebagai pemeran kedua dalam menunjang ekomoni keluarga.
\end{abstract}

Kata Kunci: Peran, Istri Nelayan, Rumah Tangga.

\begin{abstract}
ABSTRACK
Tidung Island is an area located in the South Thousand Islands, an area located near the coast. Because the location adjacent to the beach makes the highest dominant occupation, namely fishermen, in this case the role between husband and wife contributes, a number of fishermen's wives are not only busy in taking care of household activities such as cleaning family clothes, cooking, providing food, cleaning the house, washing clothes, and educate children. But more than that, it has become a consequence of fishermen's wives that sometimes the income from fishermen is uncertain all the time, therefore the involvement of fishermen's wives in helping support the family economy and earning a living to meet their daily needs creates a dual role. The purpose of this study was to determine the role of fishermen's wives in improving the household economy. This research uses a qualitative approach with descriptive research or case studies taking informants taken by purposive sampling while the data collection techniques used are in-depth interview techniques and direct observation. That the role of the fisherman's wife is, among others, as a fish seller and determines the selling price of fish.
\end{abstract}

Keywords: Role, Fisher Wife, Household. 


\section{PENDAHULUAN}

Indonesia merupakan negara kepulauan yang terdiri dari 16.684 pulau yang tersebar di berbagai pelosok nusantara dan merupakan negara kepulauan yang sebagian besar wilayah adalah pesisir. Menurut data BPS Secara astronomis, Kabupaten Administrasi Kepulauan Seribu terletak $5^{\circ} 10^{\prime} 00^{\prime \prime}$ sd 5 57 $57^{\prime} 0^{\prime \prime}$ Lintang Selatan dan 106 $19^{\prime} 30^{\prime \prime}$ sd 106 $44^{\prime} 50^{\prime \prime}$ Bujur Timur. Kabupaten Administrasi Kepulauan Seribu merupakan dataran rendah dengan ketinggian rata-rata +1 meter diatas permukaan laut. Luas wilayah Kepulauan Seribu, berdasarkan SK Gubernur Nomor 171 tahun 2007, adalah 8,70 km2. Wilayah Kepulauan Seribu memiliki tidak kurang dari 110 buah pulau. Berdasarkan posisi geografisnya, Kabupaten Administrasi Kepulauan Seribu memiliki batas-batas di sebelah utara dengan Laut Jawa, Selat Sunda; sebelah timur dengan Laut Jawa; sebelah selatan dengan Kota Administrasi Jakarta Utara, Kota Adm. Jakarta Barat dan Kabupaten Tangerang; dan sebelah barat dengan Laut Jawa atau Selat Sunda. Wilayah administrasi Kepulauan Seribu terbagi menjadi 2 wilayah kecamatan dan 6 kelurahan. Wilayah kepulauan berjarak 32 mil dari Jakarta. Jika menggunakan kapal feri tradisional dari Muara Angke jarak tempuhnya selama 2 jam akan tetapi jika menggunakan kapal speedboat jarak tempuhnya selama 90 menit. Letak geografis Pulau Tidung membuat masyarakat di dalamnya sebagian besar berprofesi sebagai nelayan karena mudah dan tidak memerlukan syarat khusus untuk bekerja didalamnya. Nelayan adalah mereka yang berada di wilayah pesisir dan bekerja sebagai pencari ikan.

Perolehan ikan didistribusikan kepada konsumen dengan menjadikan istri nelayan sebagai perantara penjual ikan keliling utama, artinya para istri nelayan tersebut mengelilingi kelurahan Pulau Tidung sambil menawarkan hasil tangkapan laut tersebut. Para istri nelayan tersebut berkeliling menawarkan ikan pada saat pagi dan sore hari, atau menawarkan melalui online. Tujuannya agar ikan yang dijual sampai ke konsumen tidak basi atau tetap segar, sehingga kualitas masih terjamin. Faktor yang mempengaruhi istri nelayan sebagai pedagang utama dalam menjual ikan di pulau Tidung adalah karena para nelayan tidak memiliki tempat untuk mendistribusikan hasil tangkapan laut, jika harus ke Jakarta akan membutuhkan biaya dan waktu lebih sedangkan para nelayan tersebut belum mampu jika menggunakan biaya sendiri. Oleh karena itu, para istri menjadi penengah atas keresahan yang dialami para nelayan tersebut. Satu sisi lain perempuan memiliki peran ganda yang dituntut harus bisa mengolah dan membantu perekonomian keluarga. Istri dari nelayan tersebut ikut andil dalam bekerja dan berpartisipasi mencari nafkah agar menambah pendapatan keluarganya. Tujuan dari penelitian ini yakni untuk mengetahui peran istri nelayan dalam membantu untuk meningkatkan perekonomian keluarga. 


\section{METODE PELAKSANAAN}

Penelitian yang dilakukan pada tahun 2021 di Pulau Tidung ini bertujuan untuk menganalisis dan mendeskripsikan peran istri nelayan dalam meningkatkan perekonomian rumah tangga. Metode penelitian yang digunakan yakni metode penelitian pengumpulan kualitatif.

Penyelidikan informasi bersifat induktif/subyektif, dan konsekuensi dari eksplorasi subjektif lebih diringkas. Pengambilan informan dilakukan secara purposive sampling. Purposive sampling adalah teknik pengambilan sampel sumber data dengan pertimbangan tertentu. Pertimbangan tertentu ini misalnya orang tersebut yang dianggap tahu tentang apa yang kita harapkan atau mungkin dia sebagai penguasa sehingga akan memudahkan peneliti menjelajahi obyek atau situasi yang diteliti. Atau dengan kata lain pengambilan sampel diambil berdasarkan kebutuhan penelitian. Penelitian ini menjadikan 3 orang istri nelayan sebagai narasumber dan 3 orang nelayan sebagai Kepala Keluarga sebagai narasumber. Penelitian ini membutuhkan waktu selama 30 hari dan dilakukan di Kelurahan Pulau Tidung.

\section{HASIL DAN PEMBAHASAN}

\section{Kondisi Umum Lokasi Penelitian}

Kelurahan Pulau Tidung terletak di Kecamatan Kepulauan Seribu Selatan, Kota Jakarta, Provinsi DKI Jakarta. Kelurahan yang berada di Kecamatan Kepulauan Seribu Selatan ini memiliki 3 kelurahan salah satunya yakni Pulau Tidung. Pulau Tidung juga memiliki pulau yang memang bisa dikatakan menyatu antara pulau kecil (Tidung kecil) dan pulau tidung (Tidung besar) itu sendiri. Pulau Tidung besar yang memang digunakan sebagai tempat huni masyarakat dan pulau kecil hanya digunakan untuk tempat pelestarian alam, seperti tempat penanaman mangrove. Pulau Tidung selain sebagai tempat tinggal, juga sebagai tempat pariwisata.

Kepala Lurah di Kelurahan Pulau Tidung sampai dengan sekarang adalah Hafsah, S.K.M. menjabat sebagai Lurah pada tanggal 14 Februari 2021 sampai dengan sekarang. 


\section{Jumlah Penduduk}

Tabel 1.

Keseluruhan penduduk Kelurahan Pulau Tidung, Kecamatan Kepulauan Seribu Selatan, Kota Jakarta

\begin{tabular}{cccccccc}
\hline \multirow{2}{*}{ Wilayah } & \multicolumn{3}{c}{ Total Penduduk } & \multicolumn{3}{c}{ Jumlah KK } & \multirow{2}{*}{ KET } \\
\cline { 2 - 6 } & L & P & JML & L & P & JML & \\
\hline RW 1 & 638 & 647 & 1.285 & 317 & 56 & 373 & 7 RT \\
RW 2 & 740 & 724 & 1.464 & 358 & 53 & 411 & 7 RT \\
RW 3 & 909 & 970 & 1.879 & 456 & 74 & 530 & 9 RT \\
RW 4 & 573 & 538 & 1.111 & 283 & 36 & 319 & 6 RT \\
\hline JUMLAH & $\mathbf{2 . 8 6 0}$ & $\mathbf{2 . 8 7 9}$ & $\mathbf{5 . 7 3 9}$ & $\mathbf{1 . 4 1 4}$ & $\mathbf{2 1 9}$ & $\mathbf{1 . 6 3 3}$ & 29 RT \\
\hline
\end{tabular}

Tabel 1 di atas melihatkan bahwa total keseluruhan penduduk yang berada di Kepulauan Seribu Selatan khusus nya Pulau Tidung yakni 5.739 Jiwa yang terdiri dari 2.860 orang lakilaki dan 2.879 jiwa perempuan dengan jumlah KK sebesar 1.633 jiwa.

Kelurahan Pulau tidung merupakan Kelurahan yang cukup padat dibanding dengan Kelurahan lain yang berada di Kepulauan Seribu Selatan. Salah satu penyebab kepadatan penduduk Pulau Tidung yakni banyaknya warga pendatang dari luar daerah Pulau Tidung itu sendiri, baik karena pernikahan, atau bahkan mencari pekerjaan mengingat potensi sumber daya kelautan yang cukup tinggi baik.

\section{Mata Pencaharian}

Tabel 2.

Mata pencaharian Kelurahan Pulau Tidung

\begin{tabular}{cccccc}
\hline \multirow{2}{*}{ No. } & \multirow{2}{*}{ Wilayah } & \multicolumn{4}{c}{ Macam-macam Mata pencaharian } \\
\cline { 3 - 6 } & & Nelayan & Pedagang & PNS & Petani Rumput Laut \\
\hline 1 & RW 1 & 84 & 63 & 45 & 2 \\
\hline 2 & RW 2 & 72 & 105 & 53 & 7 \\
\hline 3. & RW 3 & 124 & 94 & 32 & 25 \\
\hline 4. & RW 4 & 114 & 49 & 29 & - \\
\hline & JUMLAH & 394 & 311 & 159 & 69 \\
\hline
\end{tabular}

Sumber: kantor Kelurahan Pulau Tidung, 2021.

Dapat dilihat dari tabel 2, bahwa mata pencaharian penduduk yang ada, dapat dikatakan bermacam-macam dimana mereka memiliki sumber penghasilan yang bervariasi karena pada dasarnya pekerjaan yang berbeda membuat hasil yang didapat juga berbeda. Oleh sebab itu pekerjaan yang paling dominan dari pekerjaan-pekerjaan yang lainnya yaitu, nelayan karena letak wilayah yang sangat strategis dengan pesisir, dan juga begitu dekat dengan laut maka memudahkan bagi mereka untuk mendapatkan ikan dengan jumlah yang sangat banyak. Macam-macam tangkapan ikan yang nelayan dapatkan yakni adalah ikan keakea, ikan kurisi, 
ikan tongkol, ikan kembung. Ikan-ikan tersebutlah yang memang banyak terdapat di Pulau Tidung.

Karena banyaknya sumber daya kelautan yang ada selain nelayan yang mengambil ikan ada juga yang mata pencaharian sebagai petani rumput laut, dengan sebagian besar nelayan yang ada dapat memudahkan masyarakat dalam mengkonsumsi ikan segar setiap saat nya. Karena proses pengambilan ikan yang memang langsung disajikan kepada pembeli dapat dikatakan bahwa pembeli merupakan tangan pertama setelah nelayan. Dan terdapat juga para pedagang yang sangat terbantu akan adanya nelayan, karena Pulau Tidung termasuk juga tempat wisata maka banyak pula pedagang rumah makan yang sangat membutuhkan hasil dari tangkapan nelayan, sehingga antara nelayan maupun pedagang sama-sama saling menguntungkan. Kelurahan Pulau Tidung juga memiliki pekerjaan di sektor pemerintahan seperti PNS dan terdapat juga pegawai swasta.

\section{Keluarga Nelayan}

Keluarga merupakan bagian terpenting dalam suatu rumah tangga yang didalamnya memiliki peran yang berbeda-beda seperti bapak yang memiliki peran untuk mencari nafkah terutama di bidang nelayan. Dan ibu berperan untuk mengurus kegiatan rumah tangga akan tetapi, segala bentuk peran yang dijalankan dalam keluarga nelayan, semua sama-sama memiliki kebaikan. Nelayan merupakan keluarga yang mata pencarian utama nya menangkap ikan di laut, karena letak wilayah di daerah pesisir membuat sebagian besar pencari nafkah di sektor perikanan atau sebagai nelayan.

Seperti narasumber yang bekerja sebagai nelayan, Bapak Tarsin 57 tahun. Ia mengatakan bahwa pekerjaan yang memang merupakan ranah laki-laki pesisir sebagai nelayan, pekerjaan yang membutuhkan fisik, tenaga yang kuat dan cekatan dalam mencari ikan di laut sangat dibutuhkan, nelayan merupakan mata pencarian yang sudah dijalankan sejak lama. Hasil dari nelayan tidak menentu setiap waktu, faktor cuaca sangat mempengaruhi pendapatan hasil nelayan.

Kemudian Bapak Ma'mun 32 Tahun, Ia mengatakan bahwa nelayan merupakan pekerjaan mencari ikan, kegiatan yang dilakukan untuk memenuhi kebutuhan keluarga karena hasil dari pendapatan yang didapat untuk memenuhi kebutuhan. Ikan yang di dapat juga mempengaruhi pendapatan, seperti ikan tongkol, ikan tenggiri, dan ikan keakea. Teknik dalam memancing juga sangat mempengaruhi dalam menangkap ikan. 
Bapak Robet 40 Tahun ia mengatakan bahwa nelayan merupakan pekerjaan untuk mencari ikan, pekerjaan ini dilakukan untuk mencukupi kebutuhan keluarga nya karena hasil dari nelayan ini mampu mencukupi sedikit-demi sedikit kebutuhan rumah tangga.

Semua kegiatan dan peran yang dilakukan baik istri maupun suami sama-sama memiliki timbal balik untuk keluarga, seperti suami mencari nafkah dalam mendapatkan ikan dan istri memiliki peran dengan menjualkan ikan tangkapan kepada masyarakat.

\section{Peran Istri Nelayan di dalam Rumah Tangga}

Aktifitas ini dikerjakan oleh istri nelayan dalam pengolahan baik dari segi waktu maupun kegiatan rumah tangga itu sudah menjadi tanggungan atau bahkan dapat dikatakan sebagai kewajiban sebagai perempuan khususnya ibu rumah tangga. Kegiatan yang tidak kenal waktu dan harus tetap dilakukan untuk keluarga seperti mencuci baju, memberi makan keluarga, mencuci piring, dan mengasuh anak bahkan harus membersihkan rumah agar tetap bersih dan tidak kotor. Dan kegiatan itu pun dilakukan setiap hari nya sehingga tidak mengenal batas waktu ketika melakukannya.

Seperti 3 orang ibu rumah tangga yang berasal dari seorang istri nelayan, peneliti melakukan wawancara terkait kegiatan yang dilakukan dalam rumah tangga. Ibu satariyah 56 tahun, Ia mengatakan bahwa segala kegiatan awal dilakukan pada pukul 05.00 WIB. Pada waktu itu Ia membeli sarapan untuk keluarganya, ketika semua keluarganya sudah mulai menjalankan aktivitas masing-masing. Pada jam 09.00 WIB Ia mulai melakukan kegiatan bersih-bersih rumah seperti memasak untuk makan siang, mencuci baju. Kemudian pukul 12 Siang adalah waktu Ia istirahat, sholat dan makan. Kemudian pada sore hari Ia harus menjemput suami nya yang sudah pulang sehabis nelayan. Ia pun menjajakan hasil tangkapan ikan tersebut kepada masyarakat, yang terkadang Ia kelilingi ataupun secara online. Setelah Ia menjualkan hasil tangkapan suami nya Ia pun kembali kerumah dan membersihkan nya, kemudian memasak untuk makan malam keluarganya.

Kemudian Ibu Heni 30 tahun mengatakan bahwa pekerjaan rumah memanglah tanggung jawabnya sebagai seorang istri, kegiatan seperti bersih-bersih pun sudah menjadi hal biasa, kegiatan yang Ia lakukan mulai pukul 06.00 WIB pagi. Saat itu Ia memasak untuk sarapan pagi untuk anggota keluarganya. Ia juga mengatakan bahwa di masa pandemi sulit mengatur waktu disisi lain, Ia harus mengurus anak dan disisi lain harus mengerjakan kegiatan rumah. Karena di masa pandemi ini anak-anak harus belajar dari rumah, Ia mengajarkan anak nya untuk belajar dari rumah yang biasanya di sekolah, ditambah lagi Ia memiliki anak bayi dan disitulah Ia merasa kerepotan. Ia hanya melakukan kegiatan yang mudah saja seperti 
menyapu, mencuci piring, dan memasak. Setelah menjalankan kewajiban untuk mengurus anak atau membersihkan rumah, Ia hendak menjemput suami nya yang sudah pulang ketika pergi nelayan, kemudian menjualkan secara online.

Berikutnya narasumber ke 3 yang peneliti mewawancarai yaitu Ibu Leha 38 tahun, mengatakan bahwa ia memulai aktifitas pada jam 06.00 WIB, kemudian Ia memasak makanan untuk keluarganya, pada pukul 10.00 WIB Ia mulai melakukan kegiatan bersihbersih rumah dengan mencuci baju, menyapu, memasak untuk keluarga dan juga mengurus anak. Jam 12.00 WIB waktunya untuk istirahat, sholat dan makan, Kemudian pada jam 5 sore Ia menjemput suaminya yang baru pulang nelayan, kemudian ia menjajakan hasil tangkapan ikan kepada masyarakat.

Walaupun pekerjaan yang dilakukan sangat menyita waktunya, tetapi istri nelayan tetap melakukan kegiatan tersebut, karena semua yang dikerjakan merupakan kewajiban yang harus dijalani dan mereka tidak pernah mengeluh atas peran ganda yang harus mereka jalani. Akan tetapi kegiatan yang dilakukan istri nelayan terhadap kegiatan rumah tangga, tidak membuatnya lelah untuk mencari nafkah dan membantu kegiatan ekonomi keluarganya. Disamping menjual ikan untuk membantu kegiatan ekonomi keluarga, Istri nelayan juga memiliki pekerjaan sampingan dengan berjualan online baik itu menjual baju ataupun makanan.

\section{Ukuran Keluarga Nelayan}

Ukuran keluarga begitu sangat penting dan diperhatikan seperti jumlah anggota keluarga yang ada di dalam rumah tangga sangat begitu mempengaruhi tingkat kemakmuran di dalam keluarga itu sendiri, karena semakin banyaknya tanggungan anggota keluarga yang ada maka semakin besar pula pengeluaran dan kebutuhan dan semakin besar juga pendapatan yang harus didapatkan. Untuk mencukupi kebutuhan baik makanan dan kebutuhan lainnya. Akan tetapi sebaliknya jika anggota yang ada dalam keluarga itu didalamnya terdapat tanggungan yang sedikit maka untuk dapat memenuhi kebutuhan nya akan sangat lebih mudah atau ringan karena dengan jumlah yang tidak terlalu banyak pengeluaran untuk kebutuhan pun sedikit pula yang harus dikeluarkan, maka dari itu sangat penting memperhatikan ukuran yang ada dalam rumah tangga.

Menurut Mantra (2003), setiap orang dalam keluarga dan individu yang terlibat atau bahkan makan di bawah atap yang sama dengan dapur dengan orang-orang yang sekarang berada di kelas kerja atau kerja. Pentingnya atap adalah semua kebutuhan sehari-hari bersama-sama menjadi satu. Bisa dikatakan bahwa bertempat tinggal dengan sanak saudara adalah seseorang 
yang tidak dapat membayar kebutuhannya karena tidak memiliki pekerjaan yang baik karena saat ini mereka tidak berguna atau bahkan orang yang sangat membutuhkan bantuan orang lain.

Seperti halnya 6 responden yang ada dari 3 istri nelayan dan 3 lainnya dari kepala keluarga atau nelayan itu sendiri yang diwawancarai mengenai jumlah anggota keluarga beserta tanggungan-tanggungan dari tiap-tiap anggota keluarga nya. Narasumber yang pertama, ia mengatakan bahwa di dalam rumah tangga nya ia memiliki 4 tanggungan yang harus di beri kebutuhan yang cukup baik dan hal ini lah yang membuat istri dari nelayan tersebut amat sangat merasa kesulitan, karena tanggungan yang dirasa banyak dan kebutuhan yang terus bertambah. Karena seringkali tidak bisa untuk mencukupi masalah kebutuhan yang ada. Tanggungan kebutuhan yang ditanggung oleh istri nelayan juga bukan hanya perihal makanan semata. Akan tetapi kebutuhan yang secara keseluruhan seperti rumah untuk tempat nya tinggal, dan baju untuk anak maupun suami nya atau bahkan biaya sekolah untuk anak nya dan hal inilah yang dikatakannya memang dirasa berat.

Hal ini berkaitan dengan pendapatan yang ia dan suami nya dapatkan belum begitu cukup memenuhi. Berikutnya narasumber yang kedua yang dimana ia memiliki tanggungan dalam rumah tangga yakni 2 tanggungan akan tetapi hal ini membuat istri nelayan tersebut merasa mampu dan bisa dalam mencukupi kebutuhan untuk tanggungan yang ada di dalam rumah tangga nya. Kebutuhan yang dikeluarkan tidak terlalu banyak sehingga ia masih mampu untuk mencukupi kebutuhan untuk tanggungan 2 anggota keluarga yang ada dalam rumah tangga nya tersebut.

Berikutnya narasumber yang ke tiga yang dimana ia memiliki 3 tanggungan dalam rumah tangga nya dan hal ini membuat nya merasa mampu untuk mencukupi kebutuhan atas tanggungan yang ada dalam rumah tangga nya. Dan untuk narasumber yang ke empat ia memiliki tanggungan 2 dikatakan juga bahwa hal ini membuatnya merasa mampu untuk mencukupi kebutuhan tanggungan yang ada dalam rumah tangga nya. Berikutnya narasumber yang ke lima ia memiliki 3 tanggungan dan ia merasa tidak mampu untuk mencukupi kebutuhan keluarga yang ada karena ada beberapa hal yang menyebabkan tidak kesanggupan untuk memenuhi kebutuhan tanggungan yang ada dalam rumah tangga nya tersebut. Dan narasumber yang keenam memiliki 2 tanggungan yang dimana ia merasa mampu untuk mencukupi karena keperluan yang dirasa belum begitu banyak pengeluaran. Dapat dilihat dari 6 narasumber yang ada, tanggungan yang paling banyak dimiliki dalam rumah tangga nya yakni sebanyak 4 tanggungan. 


\section{Alasan Istri Nelayan Bekerja}

Masyarakat atau warga yang memang termasuk nelayan yang tinggal di kelurahan Pulau tidung dimana sebagian besar bergantung terhadap sektor perikanan yakni mencari ikan di laut atau kepiting dan bahkan kerang-kerang laut. Dan dapat diketahui bahwa penghasilan nelayan memang sangat tidak bisa dipastikan, pastinya selalu naik turun, karena beberapa alasan tersebut sehingga membuat hal tersebut terjadi diantaranya, karena keadaan mempengaruhi yakni cuaca. Apabila keadaan cuaca bagus pada saat nelayan menangkap ikan maka hasil tangkapan juga bisa dikatakan akan mendapat banyak. Hasil keuntungan juga sangat cukup untuk memenuhi kebutuhan, begitupun sebaliknya jika cuaca tidak bersahabat maka pendapatan ikan juga menurun. Terlebih lagi jika sudah turun angin barat daya dimana keadaan laut sudah tidak dapat dipastikan dengan tenang dan disitulah bisa dikatakan musim paceklik bagi masyarakat nelayan di kelurahan pulau tidung, karena jika sudah turun angin barat daya tersebut para nelayan tidak dapat menangkap ikan dalam kurun waktu 1-2 bulan contohnya seperti pada saat turun angin barat daya laut menjadi tidak tenang dan ombak besar yang disitulah mempengaruhi ikan karena pada dasarnya ikan hidup di keadaan laut yang tenang sehingga mengapa dikatakan cuaca sangat mempengaruhi pendapatan. Berhubungan dengan hal ini seorang istri nelayan yang menjadi narasumber mengatakan apabila musim barat daya banyak nelayan tidak melaut dan bahkan mereka mencari pekerjaan sampingan bisa dikatakan pekerjaan serabutan selepas nelayan karena untuk menambah penghasilannya, karena mereka beranggapan pekerjaan apapun yang dijalani dan yang didapatkan merupakan rezeki yang harus diambil dan harus disyukuri karena dengan bekerja akan membuahkan hasil dan manfaat yang didapat cukup untuk mengisi kebutuhan keluarganya.

Penghasilan yang didapat sangat tergantung pada beberapa faktor seperti cuaca dan musim, sehingga berdampak pada pendapatan yang tidak menentu. Hal inilah menjadi pertimbangan bagi seorang istri untuk bekerja dan berusaha, bahkan ketika melihat kebutuhan hidup yang harus dipenuhi dan kebutuhan-kebutuhan yang terus menerus menaik itulah, yang membuat keperluan rumah tangga tidak tercukupi. Jika hanya menggantungkan harapan hanya pendapatan kepada pendapatan nelayan saja maka dari itu, mau tidak mau istri dari nelayan tersebut juga ikut membantu dalam kegiatan ekonomi, jika istri tidak ikut membantu perihal ekonomi maka tingkat kesejahteraan dalam keluarga tersebut sangat tidak stabil. Karena mereka tidak mau anaknya seperti mereka yang hanya tamat sampai jenjang Sekolah Dasar maka dari itu mereka berupaya dan berusaha sekuat tenaga untuk mendapatkan pendapatan demi menyekolahkan anaknya ke tahap yang lebih dan jenjang yang lebih tinggi, jika memang mencukupi hingga ke jenjang perkuliahan alasan inilah yang paling terkuat selain 
kebutuhan sehari-hari sehingga menggerakan hatinya untuk terus bertahan hidup jika mengingat hal itu.

\section{Pengeluaran Rumah tangga Nelayan}

Pengeluaran dari kebutuhan rumah tangga nelayan yakni, kurang lebih Satu juta delapan ratus ribu rupiah sampai dua juta lima ratus ribu rupiah setiap bulan nya, pengeluaran yang dikeluarkan guna untuk memenuhi keperluan tiap harinya itu sendiri baik itu kebutuhan pangan seperti, sembako untuk makan tiap hari nya, terlebih lagi bagi para nelayan yang memang membutuhkan kebutuhan solar untuk kapal laut dan juga untuk kebutuhan biaya pendidikan sekolah anak, kebutuhan untuk membayar kontrakan, atau bahkan kebutuhan untuk membayar rumah seperti listrik, dan pengeluaran kegiatan sosial, pengeluaran untuk membayar arisan. Akan tetapi tak jarang dari mereka yang mengeluarkan uangnya untuk ditabung karena ditakutkan terdapat kejadian yang tidak diinginkan, jika ada kendala atau masalah yang tidak terduga maka uang tabungan tersebutlah yang akan dikeluarkan untuk dipakai. Pengeluaran yang sangat tidak menentu yang terkadang membuat pengeluaran bisa lebih dari target atau juga kurang dari target maka dari itulah yang tidak dapat diprediksi.

\section{Pembagian Waktu Istri Nelayan}

Perempuan memang sudah ditakdirkan dan bahkan stigma masyarakat terkait istri yakni, suatu pengabdian terhadap suami atau bahkan terhadap anaknya hanya untuk mengurus rumah tangga, mengurus anak-anak dan membersihkan kegiatan didalam rumah, tanpa melihat ternyata ada perempuan lah atau istri di dalam kegiatan sehari-hari mengurus rumah akan tetapi, disisi lain istri juga memikirkan bahkan ia juga membagi waktunya untuk membantu dalam kegiatan perekonomian keluarganya yang dimana istri juga mampu dalam memegang keuangan dan bahkan mengatur keuangan. Sudah memang selayaknya seorang istri pintar dalam membagi tugas ketika ia harus mengurus rumah, dan mengurus pekerjaan.

\section{Peran Istri Nelayan dalam Bidang Ekonomi}

Peran untuk mencari nafkah memang biasanya dilakukan oleh suami sebagai kepala keluarga yang memang seharusnya mencukupi kebutuhan ekonomi akan tetapi dalam keadaannya apalagi di zaman yang sudah berkembang seperti ini banyak istri yang ikut andil dan mampu mengekspresikan kemampuan nya dalam mencari nafkah dan untuk mencukupi kebutuhan bagi keluarga dirumah. Peran dalam kegiatan sampingan dari seorang istri dikerjakan dari selain hanya menjadi ibu rumah tangga saja. 
Istri dari nelayan yakni sekarang sudah memiliki kegiatan sampingan atau pekerjaan sampingan yang dapat mampu menunjang pendapatan suami yang dapat dikatakan belum cukup untuk memenuhi kebutuhan rumah tangga. Pekerjaan atau usaha sampingan apapun ia lakukan guna menambah sedikit demi sedikit rupiah yang diperlukan untuk keperluan pengeluaran kebutuhan hal tersebut adalah upaya dalam mencukupi pendapatan guna mencukupi dalam keluarga nya.

Usaha atau kegiatan ekonomi yang dilakukan istri nelayan pada dasarnya kebanyakan dari usaha sendiri, karena dengan usaha sendiri istri nelayan dapat mengekspresikan apa yang ia inginkan seperti, dan juga terdapat istri nelayan yang membuka usaha kecil-kecilan sendiri seperti membuat kue basah, gorengan sehingga tidak terikat karena dikatakannya dengan memiliki usaha sendiri, dan dimana usaha itu ditempatkan di depan rumahnya maka sangat memudahkan bagi istri nelayan tersendiri untuk sekaligus mengurus anak dan mengurus rumah, akan tetapi semua kembali kepada pilihan masing-masing.

Bahkan ada juga terdapat istri nelayan terjun langsung untuk bekerja dalam bidang perikanan seperti hal nya ketika suami sebagai penangkap ikan dan istri sebagai pengolah ikan yang nantinya akan diproduksi sebagai kerupuk ikan, kerupuk cue, dan dijual sebagai lauk pauk bahkan hanya sekedar dimasak demi mencukupi keinginan.

Terdapat juga seorang istri nelayan melakukan pekerjaan sampingan, di masa sekarang banyak yang mengandalkan pedagang online, dan ia menjual baju, bahkan makanan yang di unggah dalam media sosial sebagai pemasarannya dan banyak dari mereka yang tertarik terjun menjadi pedagang online karena dirasa sangat mudah, karena dapat berjualan di dalam rumah hanya mengandalkan ponsel dan selebihnya ia mampu berjualan sembari mengurus hal lain maka dari itu tak jarang istri dari nelayan membuka usaha online ini karena daripada menganggur dan bahkan tidak sama sekali mendapatkan hasil oleh karena ia berinisiatif untuk membuka usaha online ini.

Bahkan juga terdapat pekerja serabutan yang terkadang tidak menentu seperti kuli menyuci, kuli memasak, atau kuli gosok baju yang dilakukan di rumah masyarakat. Maka dari itu peran istri lebih banyak karena istri dari nelayan juga mau untuk membantu terkait perannya dalam ekonomi dan dapat dikatakan suami hanya mampu menghabiskan kegiatannya atau bahkan waktunya di laut lepas guna untuk mencari ikan, sehingga ia hanya mengenal cangkupan dalam kegiatan perikanan saja akan tetapi istri lebih mampu mencari kegiatan yang lebih luas cangkupannya karena memang istri tidak hanya terpaut dalam kegiatan perikanan saja, karena cangkupan yang ia jalani lebih luas. 


\section{Pendapatan Istri Nelayan}

Pendapatan merupakan hasil yang akan diperoleh dari apa yang diusahakan sehingga hasil dari kerja keras dapat menghasilkan sesuatu seperti uang maupun barang bahkan juga jasa maka dari penghasilan yang didapat itu akan digunakan untuk membelanjakan yang sifatnya dapat mencukupi keperluan di dalam rumah tangga, dan segala sesuatu kegiatan yang dilakukan baik dari kepala keluarga ataupun dari anggota keluarga itu sendiri guna untuk mencukupi atau juga memenuhi kebutuhan dalam rumah tangga. Kegiatan sampingan yang dilakukan oleh istri nelayan guna memperoleh hasil dari usaha ataupun tenaga yang disewakan untuk memenuhi kebutuhan, pendapatan yang diperoleh dari setiap pekerjaan memang berbeda-beda karena dapat dikatakan dari segi waktu maupun jenis usaha yang dijalankan saja berbeda-beda maka sangat wajar jika terjadi perbedaan pendapatan antara satu dengan yang lainnya. Untuk istri nelayan yang mengolah makanan hasil tangkapan laut dari suaminya yakni tentu saja lebih besar dibanding dengan pedagang lainnya karena pendapatan hasil tangkapan laut (ikan) didapat oleh nelayan itu setiap hari maka dari itu pemasukan yang didapatkan selama sebulan yakni Rp.3.000.000.

Sedangkan pendapatan yang diperoleh oleh istri nelayan yang berjualan sebagai penjual kue basah dan gorengan selama satu bulan yakni memperoleh Rp.1.500.000 pendapatan yang didapat sangat mempengaruhi baik dari segi pelanggan ataupun bahan baku nya dan untuk pendapatan yang didapat oleh istri nelayan yang menjual jasa dan tenaganya seperti kuli nyuci dan kuli gosok baju, yakni sebesar Rp.50.000 - Rp. 100.000 per harinya akan tetapi berbeda dengan pendapatan setiap bulannya yakni Rp.700.000. Setiap bulannya karena tidak jarang masyarakat yang memakai kuli jasa mencuci selama satu bulan akan tetapi hanya tiga sampai sepuluh hari saja. Pekerjaan apapun akan dilakukan oleh istri nelayan tidak lagi mementingkan dan memikirkan apakah pekerjaan itu berat atau dapat membuatnya merasa malu, mereka mengesampingkan hal itu demi mencukupi kebutuhan yang harus terpenuhi dan istri nelayan selalu bersyukur atas apapun pekerjaan yang diberikan untuknya.

Maka dari dapat dilihat dari pekerjaan-pekerjaan istri nelayan itu meski kontribusi yang dilakukan oleh istri nelayan tersebut dapat dikatakan hanya sebagai pekerja sampingan saja dan juga tidak terlalu begitu banyak penghasilan yang didapatkannya akan tetapi hal ini sudah sangat dapat sedikit membantu pemasukan yang ada dalam rumah tangga bahkan peran dari istri nelayan dalam kontribusi tersebut sudah dapat dikatakan cukup membantu.

Sama halnya seperti yang dikatakan Kabir dan Huo (2011) dalam Widodo (2012) dalam keikutsertaan terhadap istri mengenai kegiatan perekonomian membuat kenaikan terikat pendapatan di dalam rumah tangga. Waktu yang sedikit mengakibatkan jam dalam pekerjaan 
istri nelayan sangat sedikit dan hal tersebut merupakan penyebab pendapatan yang diperoleh istri nelayan minim.

\section{Peran Istri Nelayan dalam bidang sosial}

Kegiatan para istri nelayan tidak hanya terpaku kepada kegiatan yang ada di dalam rumah saja seperti mengurus anak dirumah, mencuci keperluan rumah tangga, atau bahkan mengurus suami dirumah bahkan bukan hanya itu saja akan tetapi istri dari nelayan juga aktif di dalam kegiatan diluar rumah. Kegiatan yang dilakukan diluar rumah ini merupakan kegiatan yang terjun ke dalam kemasyarakatan kegiatan itu pun seperti untuk mengikuti kegiatan ibu-ibu PKK atau kegiatan Organisasi Masyarakat dalam lingkup kemasyarakatan bahkan juga kegiatan arisan, kegiatan yang dilakukan juga guna membuat istri dari nelayan ini lebih memiliki relasi atau bahkan pengetahuan yang luas dan tidak hanya terpaku kepada pemikiran terkait rumah tangga saja.

Maka dari itu banyak kegiatan positif diluar rumah yang dilakukan oleh istri nelayan sehingga Peran istri nelayan didalam organisasi juga membuat istri nelayan dapat membuatnya berekspresi dan menunjukan kemampuannya yang barangkali selama ini masih terpendam dan kegiatan diluar rumah ini seperti PKK dapat membantu juga menambah pendapatan karena dari kegiatan PKK dapat mengasah dan menyalurkan bakat seperti membuat keripik sukun dan mengolah hasil tangkapan laut seperti agar-agar laut dan ikan laut yang dibuat untuk abon ikan sehingga kegiatan positif ini selain membuat kita merasa lebih bebas berekspresi sampingannya ialah mampu menghasilkan tambahan sampingan.

Kegiatan PKK ini aktif hanya pada kegiatan tertentu seperti lomba PKK antar kelurahan atau kegiatan HUT RI dan juga kegiatan-kegiatan yang bersifat resmi lainnya karena saat kegiatan inilah seluruh ibu PKK ikut terjun langsung dalam kegiatan yang ada dan semua ikut berkontribusi untuk kegiatan PKK.

Pertemuan rapat yang diadakan satu minggu dua kali ini yang membuat kesiapan ketika ada acara dan membuat lebih bagus dan bahkan di luar dari kegiatan yang ada itulah, ibu-ibu PKK juga suka mengadakan pertemuan-pertemuan diluar kegiatan guna untuk mempererat kerukunan dan memperkuat antar anggota PKK satu sama lain kegiatan yang dilakukan makan-makan di saung, atau bahkan membuat kreasi-kreasi lainnya yang memang nantinya dipakai untuk kegiatan-kegiatan yang ada kegiatan inilah yang membuat istri nelayan merasa mampu dalam mengimbangi kegiatan yang ada.

Disisi lain terdapat juga istri dari nelayan yang memang selain mengikuti PKK saja terdapat juga ibu-ibu istri dari nelayan yang mengikuti pengajian karena mayoritas di Kelurahan Pulau Tidung adalah beragama islam sehingga pengajian ini hanya boleh diikuti oleh ibu-ibu yang 
beragama Islam jika memang ada selain islam yang memang hendak mengikuti pengajian tersebut akan di terima dan di ajari perlahan, tetapi kembali lagi pada awal karena kegiatan pengajian yang memang berkaitan dengan menambah keimanan kepada sang maha pencipta atau bahkan untuk menguatkan rasa cinta kita kepada Nya.

Bahkan disisi lain juga untuk mempererat silaturahmi antar sesama ibu-ibu anggota pengajian. Kegiatan pengajian yang dilakukan oleh anggota pengajian ini yaitu setiap siang hari yang bertempat di mushola-mushola atau bahkan di rumah-rumah dari ibu-ibu pengajian ini akan tetapi pada hari minggu kegiatan pengajian dilakukan pada pagi hari. Kegiatan yang dilakukan oleh Ibu-ibu pengajian bukan hanya sekedar mengaji dan mengkaji bahkan lebih dari itu juga terkadang anggota pengajian ini mengikuti perlombaan seperti lomba sholawat, lomba mengaji.

Terdapat juga istri nelayan yang mengikuti kegiatan arisan dan kegiatan arisan ini tidak hanya diikuti oleh istri nelayan akan tetapi membebaskan siapa saja untuk bergabung dan mengikuti arisan ini dari berbagai kalangan pekerjaan juga diperbolehkan. Disisi lain kegiatan arisan ini juga dapat mempererat hubungan antar sesama ibu-ibu yang tergabung dalam arisan ini dan kegiatan arisan ini dimaksudkan untuk menambah pendapatan sampingan. Kegiatan arisan ini diadakan oleh ibu-ibu yang awalnya ingin memiliki penghasilan tanpa bekerja maka dari itu tercipta lah kegiatan arisan ini yang memang sudah disepakati sejak awal baik dari anggota maupun jumlah uang untuk membayar arisan sudah diperhitungkan dengan sangat matang.

Dan mengingat anggota arisan ini dari seluruh kalangan dan berbagai macam pekerjaan yang ikut andil dalam kegiatan arisan ini maka kesepakatan terkait masalah terkecil sampai kepada masalah terbesar sudah dibicarakan dengan sistem musyawarah apabila tidak disepakati secara bersama secara musyawarah ditakutkan akan terjadi hal yang dirasa kurang nyaman dari salah satu anggota maka dari itu seluruh anggota diwajibkan untuk musyawarah sehingga sudah ditetapkan jika keputusan yang ada. Kegiatan arisan ini juga dilakukan dalam kurun waktu yakni selama satu bulan sekali dengan ketentuan untuk membayar Rp.20.000 setiap satu minggu sekali.

Kegiatan ini juga dijalankan di rumah-rumah aggota dari mereka yang mengikuti arisan tidak hanya terpaku dirumah saja agar lebih dapat nuansa baru kegiatan arisan ini bahkan dilakukan di saung. Karena dikatakan bahwa arisan ini bukan hanya sekedar arisan akan tetapi dalam hal ini para anggota menanamkan nilai kekeluargaan agar tercipta ruang sosial yang tentram dan damai kegiatan ini juga sekaligus menguatkan dan mempererat silaturahmi yang terus berjalan antara satu anggota dengan anggota lain. Dan dikatakan oleh salah satu istri nelayan 
yang merupakan anggota dari grup kegiatan arisan ini yakni kegiatan dapat membantu dalam memenuhi kebutuhan keluarga.

\section{SIMPULAN DAN REKOMENDASI}

Berdasarkan hasil penelitian dapat disimpulkan bahwa Kepulauan Seribu, Kelurahan Pulau Tidung merupakan wilayah yang sangat strategis dengan pesisir, karena itu banyak dari warga yang berprofesi sebagai nelayan. Keluarga nelayan merupakan kegiatan dalam mengambil ikan di laut, sebagai keluarga nelayan bukan hanya suami yang diwajibkan berperan dalam mencari nafkah, akan tetapi selain suami yang berperan dalam kegiatan ekonomi istri juga memiliki andil dalam kegiatan di rumah tangganya tersebut.

Seorang Istri nelayan juga memiliki peran aktif dalam kegiatan rumah tangga yaitu peran publik maupun peran domestik dalam kegiatan rumah tangga ataupun dalam membantu perekonomian keluarga. Segala kreativitas peran yang dilakukan oleh istri nelayan yang berjualan ikan keliling atau bahkan berjualan sampingan seperti menjual kue basah dan bahkan menjual jasanya untuk mencukupi kebutuhan karena pada dasarnya istri nelayan tidak boleh hanya mengandalkan penghasilan dari suaminya saja yang mengambil ikan di laut karena pendapatan yang tidak menentu. Alasan istri nelayan bekerja juga sudah ia perhitungkan dengan matang selain karena kebutuhan yang tidak mencukupi alasan karena ingin pendidikan anak ke jenjang lebih tinggi dan itulah menjadi alasan kuat yang membuat istri tetap bertahan dan bekerja keras.

Disisi lain mereka mengurus anak ataupun mengurus rumah tangganya yang memang pada dasarnya kewajiban dari seorang istri, dan memang merupakan hak dan peran dari seorang istri harus bisa mengatur waktu baik ketika dalam mengurus rumah tangga atau mengurus kegiatan usaha yang dijalankan untuk menambah pemasukan.

\section{REFERENSI}

1. Maulana F., \& Rikrik R., (2016). Peran Istri Nelayan dalam Meningkatkan Pendapatan Rumah Tangga (Studi Kasus di Desa Panjajab, Kecamatan Pemangkat Kabupaten Sambas). Balai Besar Penelitian Sosial Ekonomi Kelautan dan Perikanan.

2. Polaria M., Djuwita R.R. Al., \& Florence V. L. (2017). 'Peran Perempuan Penjual Ikan Keliling dalam Meningkatkan Pendapatan Keluarga di Kelurahan Tumampa Dua Kecamatan Tuminting Kota Manado’. Jurnal Ilmial Agrobisnis Perikanan. 
3. Noviana B., Grace O.T., \& Victoria E.N.M. (2019). 'Peran Istri Nelayan dalam Meningkatkan Pendapatan Keluarga di Kelurahan Pasir panjang Kecamatan Lembeh Selatan Kota Bitung Provinsi Sulawesi Utara', Jurnal Ilmiah Agrobisnis Perikanan.

4. Andi K., (2017) 'Peran Istri Nelayan dalam Rangka Meningkatkan Pendapatan Keluarga', Jurnal Saintek Maritim.

5. Wahyu N.S., 'Peran dan Potensi Wanita dalam Pemenuhan Kebutuhan Ekonomi Keluarga Nelayan'. Journal of Educational Social Studies.

6. Badan Pusat Statistik (BPS) Kabupaten Kepulauan Seribu. (2021). Kabupaten Kepulauan Seribu dalam Angka 2021. CV. Dharmaputra

7. Mantjoro, E., O. Pontoh. (2003). Sosiologi Pedesaan Nelayan. Seri Dokumentasi dan Publikasi Ilmiah. Sosial Ekonomi Perikanan. Universitas Sam Ratulangi, Manado

8. Mantra, Ida Bagus. (2003). Demografi Umum, Jakarta : Pustaka Raja

9. Widodo. (2012). Peran Perempuan Dalam Sistem Nafkah Rumah Tangga Nelayan Prosiding Seminar Nasional : Jawa Timur. Kedaulatan pangan dan Energi Fakultas Pertanian Universitas Trunojoyo.

10. Koeshendrajana, S., T. Apriliani dan M. Fidaus. (2012). Peningkatan Efektifitas dan Efisiensi Usaha Perikanan Tangkap Laut Skala Kecil Melalui Fasilitasi Peta Perkiraan "Fishing Ground". Jurnal Kebijakan Sosial Ekonomi Kelautan dan Perikanan Vol.2 No.1. Jakarta.

11. Sugiyono, (2008). Metode Penelitian Kuantitatif Kualitatif dan R\&D, (Bandung: Alfabeta), 300 . 